\title{
KARST LANDFORMS IN AN INTERIOR LAYERED DEPOSIT WITHIN THE COPRATES CHASMA, MARS
}

\author{
KRAŠKE OBLIKE NA PLASTNATIH USEDLINAH V COPRATES \\ CHASMI, MARS
}

\author{
Davide BAIONI ${ }^{1}$, Nadja ZUPAN HAJNA² \& Forese Carlo WEZEL ${ }^{3}$
}

\begin{abstract}
UDC 551.435.8:523.43

Davide Baioni, Nadja Zupan Hajna \& Forese Carlo Wezel: Karst landforms in an interior layered deposit within the Coprates Chasma, Mars

The Coprates Chasma forms part of the backbone of the Valles Marineris canyon system. In the westernmost part of the chasma in an embayment on the northern wall a mound of layered material rises from the chasma floor and displays a characteristic dome-shaped morphology. The mineralogical characteristics of the dome and its surroundings have been determined by analysis of the CRISM (Compact Reconnaissance Imaging Spectrometer for Mars) data (image HRL00003752). The unit shows the clear signatures of kieserite, an evaporite mineral also found on Earth. Through analysis of the M.RO. HiRISE (Mars Reconnaissance Orbiter High Resolution Imaging Science Experiment images) we have investigated the dome landforms and the possible processes involved in their formation and shaping in great detail. The analysis shows that the landforms observed clearly indicate the presence of solutional processes that made those karst landforms. The results of our observation also suggest that liquid water must have existed on the dome in the past for long enough for the solution features to be formed, and that the karst landforms investigated exhibit an older erosional age or shorter than the same landforms studied in a similar kieserite dome located within Tithonium Chasma, another graben of the Valles Marineris system.
\end{abstract}

Keywords: evaporite deposits, karst, Coprates Chasma, Valles Marineris, Mars.

\author{
Izvleček UDK 551.435.8:523.43 \\ Davide Baioni, Nadja Zupan Hajna \& Forese Carlo Wezel: \\ Kraške oblike na plastnatih usedlinah v Coprates Chasmi, \\ Mars
}

Coprates Chasma tvori del osrednjega dela sistema kanjonov Valles Marineris. V njenem najzahodnejšem delu, na dnu pod severno steno, se nahaja gmota plastnatega materiala, ki kaže značilno morfologijo dome. Mineralna sestava dome in njene okolice je bila določena $\mathrm{z}$ analizami CRISM (Compact Reconnaissance Imaging Spectrometer for Mars) podatkov (image HRL00003752). Na analizirani enoti je jasen zapis kizerita, to je evaporitnega minerala, ki ga najdemo tudi na Zemlji. Z analizami MRO HiRISE (Mars Reconnaissance Orbiter High Resolution Imaging Science Experiment images) smo preiskovali površinske oblike na domi in možne procese, ki so bili vpleteni v njihov nastanek in oblikovanje. Analize so pokazale, da opazovane oblike jasno kažejo na prisotnost procesov raztapljanja, ki so tudi oblikovale tam prisotne kraške oblike. Rezultati naših opazovanj tudi nakazujejo, da je na površju dome v preteklosti morala obstajati tekoča voda in to zadosti dolgo, da so lahko nastale korozijske oblike; ter da preiskovane kraške oblike kažejo starejše erozijske starosti ali krajši čas delovanja vode, kot enake oblike, ki so bile preiskovane na podobni kizeritni domi v Tithonium Chasmi, drugem jarku sistema Vales Marineris.

Ključne besede: evaporitne usedline, kras, Coprates Chasma, Valles Marineris, Mars.

\footnotetext{
${ }^{1}$ Dipartimento di Scienze della Terra, Università degli studi di Parma, Campus Universitario, Via delle Scienze 43100 Parma (PR), Tel. e Fax 0521/905323, e-mail: davide.baioni@unipr.it

${ }^{2}$ Karst Research Institute ZRC SAZU, Titov trg 2, 6230 Postojna, Slovenia, e-mail: zupan@zrc-sazu.si

${ }^{3}$ Planetary Geology Research Group, University of Urbino “Carlo Bo" Italy, e-mail: forese-carlo.wezel@uniurb.it

Received/Prejeto: 29.9.2011
} 


\section{INTRODUCTION}

Layered deposits of Mars were first observed on Mariner 9 images and have been reported as thick deposits with internal layering, and a relative high albedo (Lucchitta et al. 1994). Significant deposits occur in almost all deep canyons of the Valles Marineris system where they are called interior layered deposits (ILD). The ILDs have been widely studied in the last few decades, but still they remain among the most puzzling and controversial of the canyons' features (Carr 2006). Recently, observations from the OMEGA spectrometer, on board Mars Express have shown the presence of hydrate minerals, in particular sulphates, in association with ILDs.

The Coprates Chasma (CC) is part of the Valle Marineris structure (Fig. 1A), a rift system that belongs to the Tharsis radial pattern of fractures (Carr 1981). Located next to the Martian equator, the Coprates Chasma extends approximately east-west for roughly $966 \mathrm{~km}(600$ miles). In the Coprates Chasma, the ILD of Late Hesperian through Middle Amazonian age (Lucchitta et al. 1994), indicated by OMEGA data to consist of magnesium sulphate (Bibring et al. 2006), are not found other than at the western end of the trough near its confluence with the Melas Chasma. A dome-shaped ILD rises from the chasma floor in the central part of an embayment lo- cated in the westernmost part of the Coprates Chasma and is the topic of this paper.

The objective of this work was, following a previous study on an ILD located in the eastern part of Tithonium Chasma (called East Tithonium Dome, ETD) that highlighted the presence of several karst landforms (Baioni et al. 2009; Baioni \& Wezel 2010), to investigate the presence of karst landforms in the ILD located in north Coprates Chasma, with the aim of obtaining more information about the morphological history and processes that affected the ILDs. To this end, a morphological analysis of the available Mars Reconnaissance Orbiter (MRO) High Resolution Imaging Science Experiment (HiRISE) images was performed with the aim of describing surface features and landforms, and, where possible, morphogenetic processes. The morphological features of the structure were investigated through integrated analysis of HiRISE, High Resolution Stereo Camera (HRSC), Mars Orbiter Camera (MOC), and Thermal Emission Imaging System (THEMIS) data. The morphometric characteristics of the structure were measured using a topographic map (50-m contour interval) built from HRSC and Mars Orbiter Laser Altimeter (MOLA) data.

\section{STUDY AREA SETTING (GEOLOGY AND MINERALOGY)}

The Coprates Chasma (Fig. 1B) extending east from the Melas Chasma, consists of several parallel sections separated by flat-topped or sharp-crested ridges depending on the width of the divides (Carr 2006). It forms part of the backbone of the Valles Marineris canyon system. The Coprates Chasma is the longest and deepest of the Valles Marineris system troughs. The trough is about $1,000 \mathrm{~km}$ long, and ranges in depth from $6 \mathrm{~km}$ in the eastern section to over $10.5 \mathrm{~km}$ in the west, with an average depth of $8 \mathrm{~km}$.

The geology is dominated by Noachian wall rock and various trough floor materials of Middle Hesperian age (Schultz 1998; Jernsletten 2004). The main canyon has a floor that displays only a small regional slope, which is relatively free of landslide debris and layered sediments compared with other Valles Marineris canyons, although it is partly blocked at its narrowest point. At the canyon's western end are some of the highest walls within the canyon system. They are roughly $10,000 \mathrm{~m}$ high, extending from under $-4,500 \mathrm{~m}$ to over 5,000 $\mathrm{m}$ in elevation (Carr 2006).The flat floor is at an elevation $9 \mathrm{~km}$ below the surrounding plains. Canyon walls are characterized by spur and gully morphology and distinct competent layers.

Recent studies (Jernsletten 2004) observing the apparent longevity of the spur and gully morphology and the topographic patterns that indicate the absence of ground ice conclude that these morphologies were formed by the action of liquid water and not by dry mastwasting above an ice-rich crust. Others studies indicate the possible presence of ice and/or snow at tropical to mid latitude regions of Mars in the Amazzonian age due to relative planet low obliquity periods (Head et al. 2005; Pacifici et al. 2009).

Distinct competent layers are observed in the slopes of the eastern Coprates Chasma where the stratigraphy consists of alternating thin strong layers and thicker sequences of relatively weak layers. The strong, competent, layers maintain steeper slopes and play a major role in controlling the overall shape and geomorphology of the chasma slopes. This different combination of layers may have a large impact on chasma and slope morphology, 


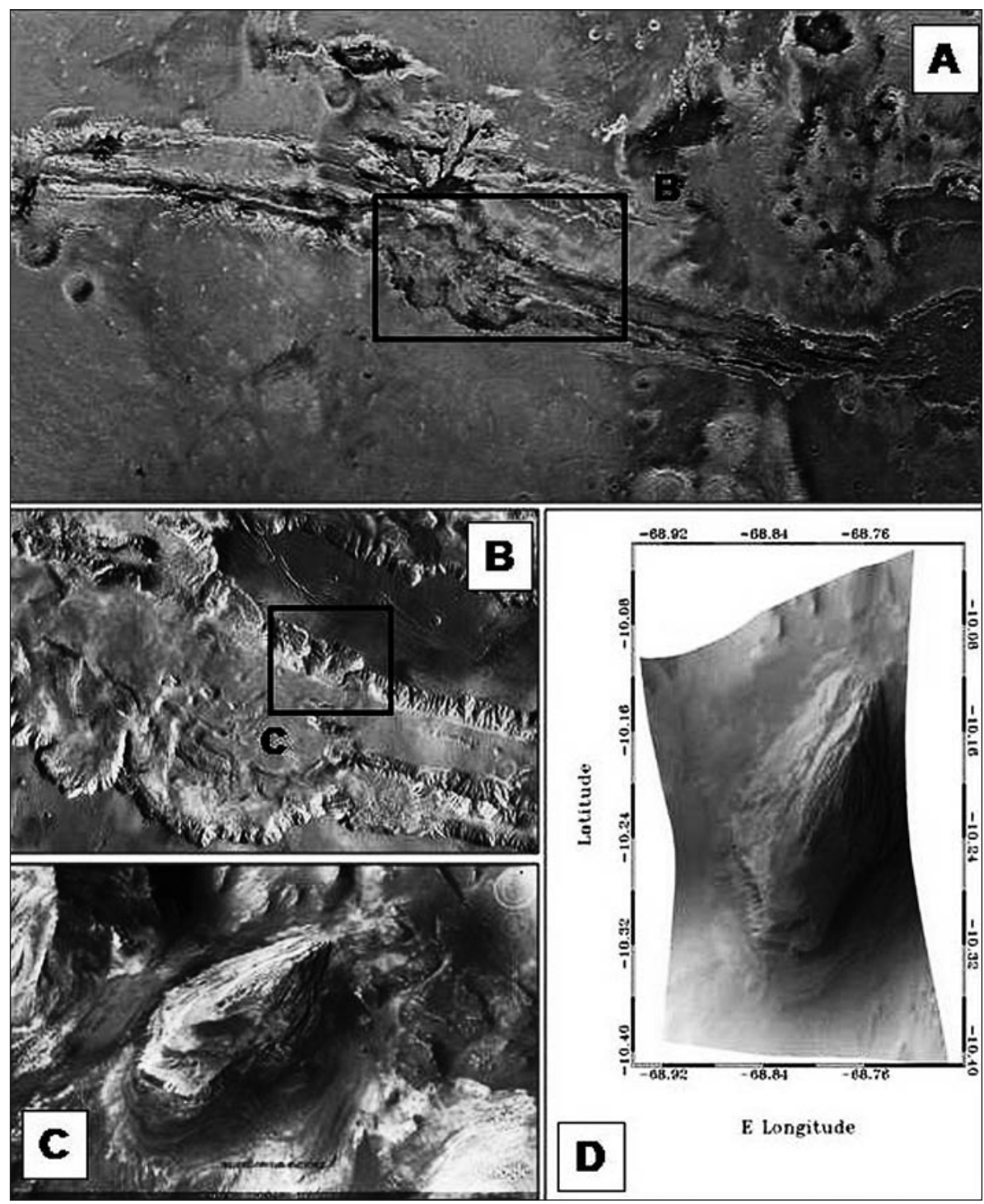

Fig. 1: (A) Valles Marineris, Mars. Location of Coprates Chasma (CC), Mars (black box). Image taken from NASA Planetary Photo Journal Collection website (www.nasaimages.org - ID 110192). (B) Image of Coprates Chasma, showing the interior layered deposit (the North Coprates Dome; NCD) at the western end of the chasma, marked by the black box. Image NASA/ USGS/ESA/DLR/FU Berlin (G. Neukum) taken from Google Mars. (C) Image of the North Coprates Dome viewed from southeast. Image NASA/USGS/ESA/ $D L R / F U$ Berlin (G.Neukum) taken from Google Mars. (D) CRISM image HRL00003752 of the NCD, acquired at $L s=153^{\circ}$.

as well as the locations and sizes of landslides (Beyer \& McEwen 2005). Along some of the walls, particularly the north walls, the downward branching spurs are truncated near their bases by fault scarp to form triangular facets. Alignment of the facets results in continuous linear escarpments hundreds of kilometers long providing compelling evidence that they are fault scarps (Carr 2006). The faults defining the northern boundary of the trough are more continuous and recently active compared with those defining the southern boundary (Schultz 1998; Peulvast et al. 2001).

In the westernmost part of the Coprates Chasma, next to the borderline with Melas Chasma, an embayment on the northern wall can be observed. The embayment displays the southern boundary formed by linear embankment trending approximately $110^{\circ}$. Along this boundary, the base of the embayment is located $1 \mathrm{~km}$ above the floor of the chasma (Fueten et al. 2010).
In the central part of the embayment, a mound of layered material, referred to as the North Coprates Dome (NCD) rises from the chasma floor and displays a characteristic dome-shaped morphology (Fig. 1C). The term dome is used from the morphological point of view and is related to the shape of the mound. It does not imply any interpretation or meaning about the processes that built the studied relief.

The NCD is approximately $12 \mathrm{~km}$ long and $8 \mathrm{~km}$ wide and its base is around 2,700 $\mathrm{m}$ above the Coprates floor. Following the terminology of Malin and Edgett (2000), that divide into three categories the layered deposits within the Valles Marineris, the NCD can be considered as composed of primarily layered units, which means that it is constituted mainly by light-to intermediate-toned "layered" units.

The mineralogical characteristics of the NCD and its surroundings have been previously determined by 
analysis of the CRISM (Murchie et al. 2007) image HRL00003752 (Fig. 1D). In particular, a recent study (Fueten et al. 2010) shows that clear signatures of kieserite $\left(\mathrm{MgSO}_{4} \cdot \mathrm{H}_{2} \mathrm{O}\right)$ can be observed both in two large regions on the floor (in the SE and SW sides of the NCD), and in a discrete number of locations on the slope of the NCD (to the SE and from the SW to the NW), while signatures of polyhydrates sulphates can be detected on the southern slope of the NCD and on the chasma floor to the north of the northern slopes.
Studies on a similar dome-shaped layered deposit (ETD) located within the Tithonium Chasma showed that the kieserite displayed on the surface could be the result of alteration processes and that the dome probably consists of the same salts that exist on Earth changing into kieserite, such as carnalite, kainite and halite (Sonnefeld 1984; Baioni \& Wezel 2008, 2010 and reference there in).

\section{NCD MORPHOLOGICAL CHARACTERISTICS}

The dome, which shows an estimated thickness of about $2 \mathrm{~km}$, rises from the chasma floor to an absolute altitude of about $200 \mathrm{~m}$ that is also the maximum elevation at which the deposits can be identified within the embayment, approximately $3.4 \mathrm{~km}$ below the elevation of the plateau (Fueten et al. 2010). The dome shows an elongate elliptical plane shape. Its longest axis displays a NNESSW-elongated trend with a length of about $17 \mathrm{~km}$, considering as part of the deposits the layers that from its southern edge can be seen extending southwards for several kilometers. Its width varies from 10 to $15 \mathrm{~km}$. The crestal region of the NCD is the central part of the structure and consists of a nearly horizontal summit plateau that is about $5 \mathrm{~km}$ long and has a maximum width of about $1 \mathrm{~km}$. It displays a very gentle slope toward south and is surrounded by steeply sloping flanks.

The NCD has a flank topography that varies in its different sectors, generally displaying higher gradient values in the western flank. In fact, the flank slopes are similar in the central and northern part of the dome, while they are very different in the southern part. In the central part of the dome, the flanks have comparatively steep slopes, ranging from $30 \%$ on the western side to $26 \%$ on the eastern side. The northern part of the dome has flanks with slope angles that range from $29 \%$ on the western sides to about $23 \%$ on the eastern sides. The asymmetric flanks of the southern part of the dome have the maximum difference in slope angles, ranging from $24 \%$ on the eastern side to $49 \%$ on the western side. Here the western flank displays the highest slope values of the entire NCD. The base of the NCD and its transition to the surrounding chasma floor and wallrock cannot be recognized. As suggested by a previous study (Fueten et al. 2010) the base of the deposit and the underlying basement can only be estimated assuming that it dips uniformly from north to south. In fact, the borderline between the base of the NCD and the chasma floor is obscured on almost all sides of the dome. On the southern, eastern and western sides the margins of the NCD are covered by fan deposits, rock debris or thin material, while on the northern and northeastern sides they seem visible and linear. In particular, on the northeastern part the NCD margin appears as a continuous straight and vertical wall that rises from the chasma floor.

\section{KARST LANDFORMS}

Typical karst corrosional surfaces formed by sheet wash and channeled water flow can be observed along the NCD flanks. Similar corrosional features have been detected also in other ILDs within the Tithonium Chasma in the northern part of the Valles Marineris canyon system (Baioni et al. 2009; Baioni \& Wezel 2010).

Different solution features were detected on the slopes of the NCD: such as karren and various depressions.

\section{KARREN FEATURES}

Karren is complex group of small- to medium-sized karst landforms of great shape variety; some of karren features can define the genetic factors of dissolution processes involved in their formation (Ford \& Williams 2007; Ginés 2009).

In the southwestern region of the dome slope, below the edge of leveled terrace (cuesta like shape), complex giant solutional channels (like wandkarren) 

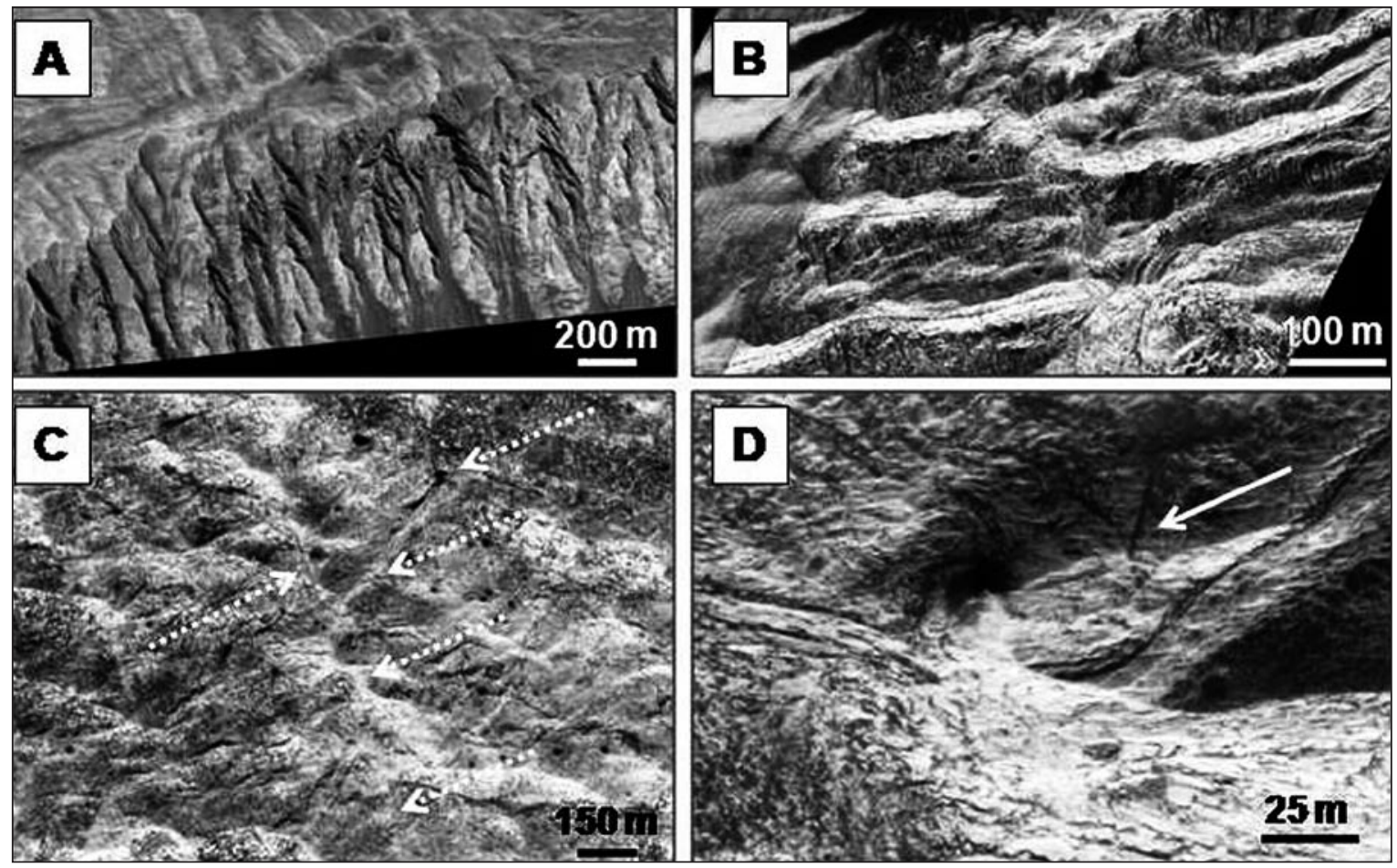

Fig. 2: (A) complex giant solutional channels (like wandkarren) on the down slope part of the south-western flank of the North Coprates Dome (MRO HiRISE image PSP_001456_1695, north toward the left of image). (B) steps like levelled surfaces on the upper part of the western flank of the NCD (MRO HiRISE image PSP_001456_1695, north toward the upper left of image). (C) Juvenile karren (white dashed arrows) on the down slope part of the western flank of the North Coprates Dome (MRO HiRISE image PSP_001456_1695, north toward the upper left of image). (D) Juvenile karren (white arrow) on the middle part of the western flank of the North Coprates Dome (MRO HiRISE image PSP_001456_1695, north toward the upper left of image). Images from HiRISE website (http://hirise.lpl.arizona.edu).

are present down the slope; these channels are evidence of water flow down the slope in the past. That they are not just erosional gullies but also corrosional features is evidenced by sharpened edges of the ridges between runnels and also the well expressed sharp edge of terrace rim at their beginning (Fig. 2A). Sharpened edges of karren forms are characteristic for dissolution by snow melting (Ginés 2009).

Leveled surfaces controlled by bedding planes are present on the western slope of the dome steps (Fig. 2B). The surfaces of the steps and slopes between them are mostly smoothed, as if they were dissolved by melting snow/ice waters like in the Alps (Ginés et al. 2009); bowl shaped shallow depressions are present on them in some places. Also some juvenile karren forms (Figs. 2C \& 2D) can be detected between single steps, sometimes starting just below the step rim or below openings along bedding planes; perhaps as the evidence of short-lived outflow (Fig. 2D). From extant features we can assume that there was not enough available water to shape more evident relief or that they were already eroded by some other processes.

\section{DEPRESSIONS}

Many closed depressions of various sizes and shapes exist on the dome flanks (Fig. 3). The process of their formation is not easy to be determined. We have no evidence if they are solution or collapse dolines or some solution pans, but their shape is not like of wind scallops at all.

The depressions on the eastern and western flanks are either bowl-shaped or rounded (Figs. 3A to 3D), they have diameters up to $50 \mathrm{~m}$, display asymmetrical walls (Figs. 3A \& 3B) and concave-up (Figs. 3A \& 3C) or have flat floor geometry (Figs. 3B, 3D \& 3E). In some cases, like on the western flank, the floors are subdivided into smaller and shallower depressions (Fig. 3E) that have diameters ranging from one to a few meters, highlighting a second generation of solution depressions. These multiple forms indicate minimum two episodes of water appearance (ice melting) on the dome surface and at least two-stage dissolution of evaporite rock during depression formation. On the upper part of the southern flank, where the incline of the slope is higher, depressions have an elongated shape with a wide 

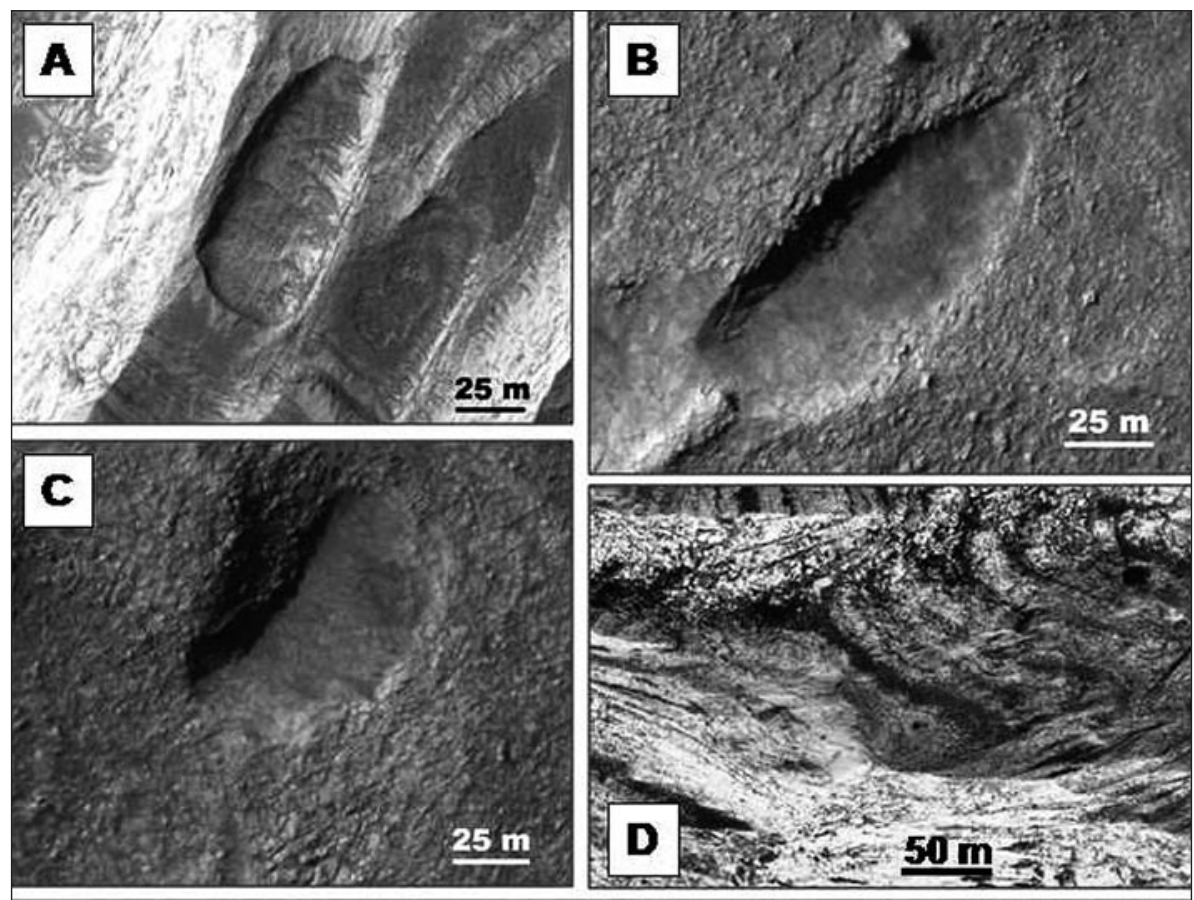

\section{E}

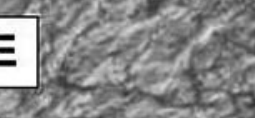

8

top and a narrow bottom (Fig. 3D). These landforms strongly resemble similar features found on the Earth displaying deep morphological similarities with dolines that develop in all kinds of evaporite and mountain karst terrains, but here were most likely formed like huge solution pans or bevels by sheet wash water flow during ice melt.

Polygonal-like karst (Williams 1972; White 1988; Ford \& Williams 2007) can be observed on the parts of the NCD that have lower slope angles, such as the down slope region of the southeastern part of the dome (Fig. 4A). Here depressions entirely pock some parts of the surface and occupy most of its area (Fig. 4B). The depressions appear to be spaced farther apart, display well defined shapes with sharp divides (Figs. 4B \& 4C) and have diameters that range from $30 \mathrm{~m}$ to more than $100 \mathrm{~m}$. This area viewed from above, has an irregular
Fig. 3: Dolines. (A) Roundedshaped doline on the western flank of the North Coprates Dome (MRO HiRISE image PSP_001456_1695, north at the top of image). (B) Roundedshaped doline with asymmetrical walls and flat floor geometry on the south-eastern flank of the North Coprates Dome (MRO HiRISEimagePSP_001456_1695, north at the top of image). (C) Bowl-shaped doline with asymmetrical walls and concave-up floor geometry on the south-eastern flank of the North Coprates Dome (MRO HiRISE image PSP_001456_1695, north at the top of image). (D) Doline with an elongated shape on the upper part of the southern flank of the North Coprates Dome (MRO HiRISE image PSP_001456_1695, north at the top of image). (E) Doline on the western flank of the North Coprates Dome, highlighting a second generation of solution depressions (MRO HiRISE image PSP_001456_1695, north at the top of image). Images from HiRISE website (http://hirise.lpl. arizona.edu). "egg-box-like" topography and the divides between adjacent depressions form a cellular mesh pattern (Fig. 4B) just as typically happens in evaporite terrains on Earth where the inherently high solubility of evaporite rocks make densely-packed depressions (Warren 2006; Ford \& Williams 2007). Because of their rounded shape these can be interpreted as dolines of polygenetic origin (Williams 1972; White 1988; Ford \& Williams 2007). But we have no evidence that the water really penetrates into evaporite rock, so they can also be formed like huge solution pans by standing or very slowly flowing water down the inclined slope. Against the hypothesis that they are formed as wind scallops is the fact that many of them are rounded and not elongated, especially those close to the slopes of the dome above the plateau. Depressions at the edges of the dolines field were most likely influenced by aeolian process, because they 

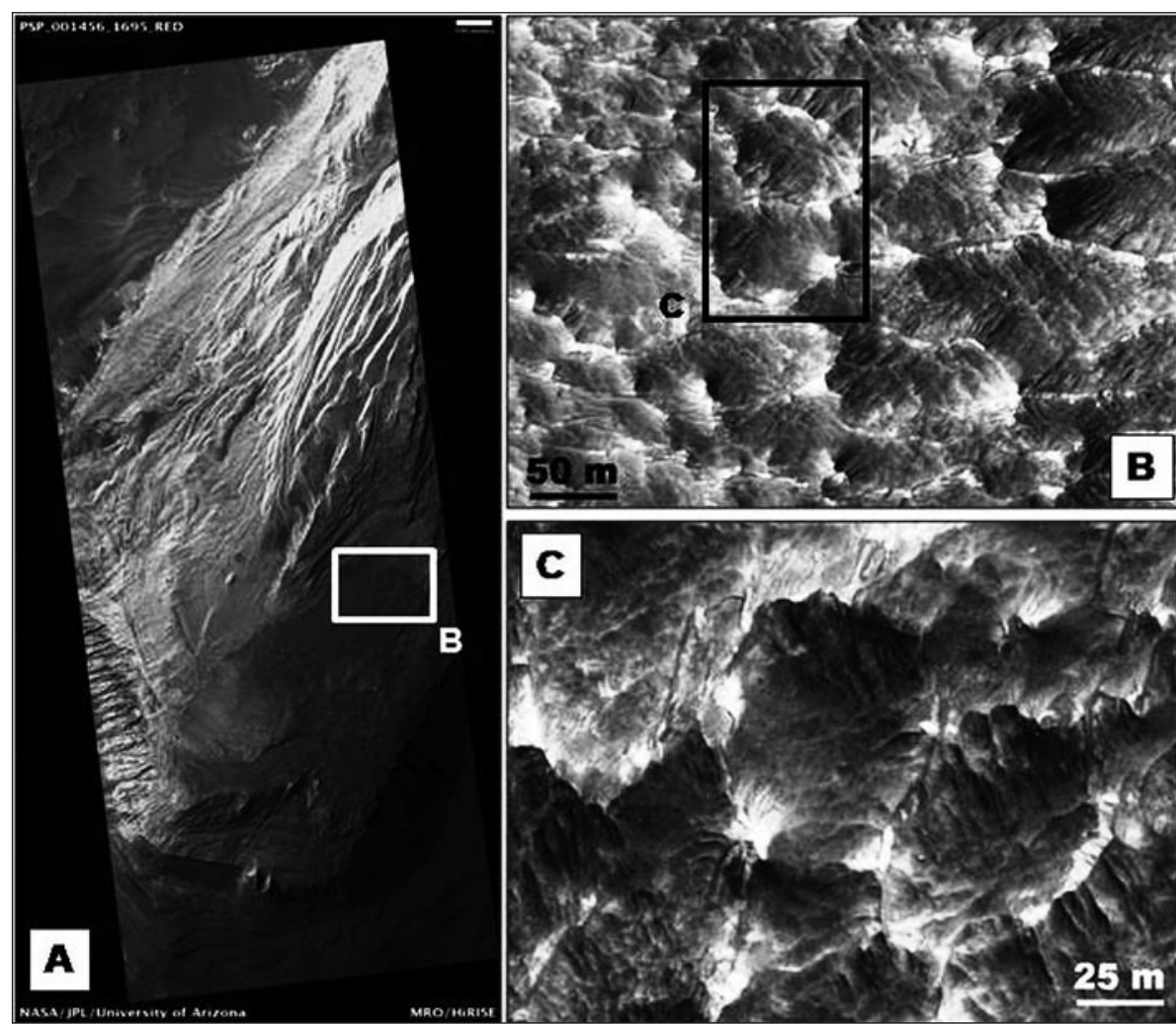

Fig. 4: Polygonal like karst landscape. (A) Location of the polygonal like karst area on the down slope region of the south-eastern part of the North Coprates Dome (MRO HiRISE image PSP_001865_1695, north at the top of image). (B) Perspective view of polygonal like karst (MRO HiRISE image PSP_001865_1695, north at the top of image). (C) Particular of the depressions displaying well defined shape with sharp divides (MRO HiRISE image PSP_001865_1695, north at the upper left of image). Images from HiRISE website (http://hirise.lpl. arizona.edu). are elongated in the wind blow direction and can be compared to the direction of the dunes in the vicinity. Elongated shape of depressions can be also interpreted as hydroaeolian landforms (Maire et al. 2009) formed by horizontal solution accelerated by wind deflection.
That means that during water existence on the surface of the NCD slopes strong and permanent winds facilitate laminar flow in direction of wind blow and solution forms are elongated along it.

\section{DISCUSSION AND CONCLUSIONS}

The presence of the described karst features on the NCD suggests their formation by laminar/sheet wash water flow which was partly canalized in runnels or wall karren. The karst features on the NCD, which were most likely formed by water during snow or ice melting, can be well correlated with the forms typical for high mountain karst regions on Earth, such as, decantation runnels, solutional bevels, tritkarren, and solution ripples (Ginés et al. 2009). The depressions observed do not display any evidence that they functioned as typical solution dolines where more rock mass is removed from their centers than from around their sides by the dissolution of infiltration water. In fact, many of them look more like solution pans or bevels (ausgleichsflächen) or closed corrosional terraces formed by melting water flowing along the surface without any or little penetration into the bedrock (kieserite).
The necessary liquid water for the solutional processes observed has been provided by melting ice or snow, which on steeper slopes can be canalized. The melting of ice or snow, which can be formed during periods of ice-snow-rich deposition from the atmosphere that may occur as the result of changes in the obliquity of Mars (Mustard et al. 2001; Laskar et al. 2004, Pacifici et al. 2009), probably occurred gradually rather than rapidly, and had to persist long enough to shape the karst landforms observed. The landforms observed on the NCD allow us to establish that the source of the water might be the melting of ice or snow rather than other different processes such us, rain or atmospheric humidity. In particular, on the down slope part in the western flank of the NCD, the presence of few lobate morphologies and some gully systems seem to indicate melting of 
ice or snow as the main processes involved in their formation and shaping.

The analysis carried out also highlights that along the NCD slopes there is no evidence of deep depressions or collapse dolines and almost no outflow evidences (just a few juvenile runnels below bedding planes), which are the only possible surface evidences of ground water existence in some stage of NCD development. In our observation of the NCD surface we did not notice any deep depressions with steep slopes, cave entrances, vadose shafts or outflow caves, as we found in a previous study in a similar evaporite dome located in the Tithonium Chasma (Baioni et al. 2009) and which represented the strong evidences of well developed and karstified underground and quite long-lasting or multiphase water existence. Karst surface and underground features are much more abundant on the ETD than on the NCD. From these facts can be anticipate that: a) less water (ice) available on the NCD; b) melting period was shorter or very fast; or c) karst features were already eroded by aeolian processes (the NCD is more exposed to the wind or karstification was older than on the ETD and erosion went on for longer time).

The characteristics of evaporite karst and its rapid formation on the Earth (Klimchouk 2004), lead us to think that liquid water existed on the NCD and persisted long enough for solution features to form but that there probably was only one episode during which water was available, but still perhaps in few events according to presence of some secondary depressions in older ones. The karstification was probably short-lived. After this period of karstification, there was no more water available and hence no additional karstification of the NCD.

The existence of liquid water that flowed gradually for a period along the NCD surface also seems to be confirmed by the landforms found at the foot of the southwestern flank. Here, systems of gullies running from the alcove sources to the fan deposits located on the base of the NCD can be clearly observed, displaying strong evidence for the presence of running liquid water.
The karst landforms observed on the NCD often appear to be partly reworked or modified by wind erosion. It has been observed that wind erosion does not affect the landform found on the dome surface in the same way. In fact, the landforms located in the down slope part of the south-western region appear less affected by wind erosion than the landforms located in all other parts. This might be explained by the different exposition to wind action. In fact, the south-western part of the NCD appears to be more protected by the wind action than by the topographic context.

The characteristics of the karst landforms and the presence of landforms with wind-related modifications might suggest that they are not of a very young erosional age. In particular, comparing (these landform) with the others found in a similar kieserite dome in the Tithonium Chasma investigated in a previous study (Baioni et al. 2009), they exhibit an older erosional age. It may be due either to the different exposition to the wind, or to the different time that they have been exposed to the wind, or, more probably, to both factors.

The analysis carried out in this study suggests that:

i) The karst landforms might be consistent with responses to climatic change and the presence of enough liquid water to form the observed landforms.

ii) There was only a single geologically short "coolwet episode" with available water during the NCD history, probably occurring in the Amazonian period, after which there was no water.

iii) The karst landforms observed in the NCD seem to be more affected and modified by wind erosion than those found and reported in a similar evaporite dome located in the Tithinium Chasma (Baioni et al. 2009), exhibiting an older erosional age. It suggests that the ILDs located in Tithonium Chasma and in the NCD might have different ages and that the NCD might be older than the ETD.

\section{REFERENCES}

Baioni, D. \& F.C. Wezel, 2008: Similarities of a Martian dome with terrestrial salt domes.- Italian Journal of Geosciences, 127, 3, 453-465.

Baioni, D., Zupan Hajna, N. \& F.C. Wezel, 2009: Karst landforms in a Martian evaporitic dome. - Acta Carsologica, 38, 1, 9-18.
Baioni, D., \& F.C. Wezel, 2010: Morphology and origin of an evaporitic dome in the eastern Tithonium Chasma, Mars.- Planetary and Space Science, 58, 847-857.

Beyer, R.A. \& A.S. McEven, 2005: Layering stratigraphy of eastern Coprates and northern Capri Chasmata, Mars. - Icarus, 179, 1, 1-23. 
Bibring, J.P., Langevin, Y., Mustard, J.F., Poulet, F., Arvidson, R., Gendrin, A., Gondet, B., Mangold, N., Pinet, P., Forget, F., \& the OMEGA team, 2006: Global Mineralogical and Aqueous Mars History Derived from OMEGA/Mars Express Data.- Science, 312, 400-404.

Carr, M.H., 1981: The Surface of Mars.- Yale Univ. Press, pp. 232, New Haven.

Carr, M.H., 2006: The surface of Mars.- Cambridge University Press, pp. 307, New York.

Ford, D.C. \& P.W. Williams, 2007: Karst Hydrogeology and Geomorphology.- Wiley \& Sons Ltd, pp. 562, West Sussex, England.

Fueten, F., Racher, H., Stesky, R., MacKinnon, P., Hauber, E., McGuire, P.C., Zegers, T. \& K. Gwinner, 2010: Structural analysis of interior layered deposits in Northern Coprates Chasma, Mars.- Earth and Planetary Science Letters, 294, 343-356.

Ginés, A., 2009: Karrenfield landscapes and karren landforms- In Ginés et al. (eds.) Karst rock features karren: sculpturing. ZRC Publishing, pp. 13-24, Postojna-Ljubljana.

Ginés, A., Knez, M., Slabe, T. \& W. Dreybrodt, 2009: Karst rock features: karren sculpturing. ZRC Publishing, pp. 561, Postojna-Ljubljana.

Head, J.W., Neukum, G., Jaumann R., Hiesinger H., Hauber E., Carr, M., Masson P., Foing, B., Hoffmann, H., Kreslavsky, M., Werner, S., Milkovich, S., Van Gasselt, S. \& The HRSC Co-Investigator Team, 2005: Tropical to mid-latitude snow and ice accumulation, flow and glaciatio on Mars.- Nature, 434, 7031, 346-351.

Jernsletten, J. A., 2004: A topographic test for the existence of ground ice in the walls of Coprates Chasma, Mars.- Journal of Geophysical Research, 109, E12004.

Klimchouk, A., 2004: Evaporite karst.- In Gunn, J. (ed.) Encyclopedia of caves and karst science. Fitzroy Dearborn, pp. 343-347, New York.

Laskar, J., Correia, A.C.M., Gastineau, M., Joutel, F., Levrard, B. \& P. Robutel, 2004: Long term evolution and chaotic diffusion of the insolation quantities of Mars. - Icarus 170, 343-364.

Lucchitta, B.K., Isbell, N.K. \& A. Howington-Kraus, 1994: Topography of Valles Marineris: implications for erosional and structural history.- Journal of Geophysical Research, 99, 3783-98.

Malin, M.C. \& K.S. Edgett, 2000: Sedimentary rocks of early Mars.- Science, 290, 1927-1937.
Maire, R., Jaillet, S. \& F., Hobléa, 2009: Karren in Patagonia, a natural laboratory for hydroaeolian dissolution.- In Ginés et al. (eds.) Karst rock features karren: sculpturing. ZRC Publishing, pp. 329-348, Postojna-Ljubljana.

Murchie, S., Arvidson, R., Bedini, P., Beisser, K., Bibring, J.-P., Bishop, J., Boldt, J., Cavender, P., Choo, T., Clancy, R.T., Darlington, E.H., Des Marais, D., Espiritu, R., Fort, D., Green, R., Guinness, E., Hayes, J., Hash, C., Heffernan, K., Hemmler, J., Heyler, G., Humm, D., Hutcheson, J., Izenberg, N., Lee, R., Lees, J., Lohr, D., Malaret, E., Martin, T., McGovern, J.A., McGuire, P., Morris, R., Mustard, J., Pelkey, S., Rhodes, E., Robinson, M., Roush, T., Schaefer, E., Seagrave, G., Seelos, F., Silverglate, P., Slavney, S., Smith, M., Shyong, W.-J., Strohbehn, K., Taylor, H., Thompson, P., Tossman, B., Wirzburger, M. \& M. Wolff, 2007: CRISM (Compact Reconnaissance Imaging Spectrometer for Mars) on MRO (Mars Reconnaissance Orbiter).- Journal of Geophysical Research, 112.

Mustard, J.F., Cooper, C.D. \& M.K. Rifkin, 2001: Evidence for recent climate change on Mars from the identification of youthful near surface ground ice.Nature, 412, 411-414.

Pacifici, A., Komatsu, G. \& M. Pondrelli, 2009: Geological evolution of Ares Vallis on Mars: Formation by multiple events of catastrophic flooding, glacial and periglacial processes.- Icarus, 202, 1-60.

Peulvast, J.P., Mege, D., Chiciak, J., Costard, F. \& P.L. Masson, 2001: Morphology, evolution and tectonics of Valles Marineris wallslopes Mars.- Geomorphology, 37, 329-352.

Schultz, R.A., 1998: Multiple-process origin of Valles Marineris basins and troughs, Mars.- Planetary and Space Science, 46, 827-834.

Sonnefeld, P., 1984: Brines and Evaporites. - Academic Press, pp. 613, London.

Warren, J.K., 2006: Evaporites: Sediments, Resources and Hydrocarbons.- Springer-Verlag, New York.

Williams, P.W., 1972: Morphometric analysis of polygonal karst in New Guinea.- Geological Society of America Bulletin, 83, 761-796.

White, W.B., 1988: Geomorphology and Hydrology of Karst Terrain. Oxford University Press, pp.464, New York. 